\title{
SELECTED PROBLEMS OF SPACE MEDICINE. EARLY PHYSIOLOGICAL RESEARCH AT THE MILITARY INSTITUTE OF AVIATION MEDICINE
}

\author{
Mieczysław WOJTKOWIAK \\ Military Institute of Aviation Medicine, Warsaw, Poland
}

Source of support: Own sources

Author's address: M. Wojtkowiak, Military Institute of Aviation Medicine, Department of Physiology, Krasińskiego 54/56 Street, 01-755 Warsaw, Poland, e-mail: mwojtkow@wiml.waw.pl

Introduction: The work is a review and an assessment of the scientific achievements of the employees of the Military Institute of Aviation Medicine (MIAM) associated with aviation and space medicine.

Methods: A retrospective analysis of studies of animals exposed to flight factors, corresponding to the weightlessness of space was performed. A decrease in the physical capacity of animals was observed on the basis of the simulated weightlessness, hypokinesia and hypodynamics. Concomitant effects of vibration and acceleration following a long-term hypokinesia resulted in the physiological disturbances of the circulatory, muscular and nervous systems of the animals. These changes were identified using radioactive isotopes. Some studies were performed in the sputniks under true space flight conditions. The effects of vibration on an organism were also analyzed and have shown that prolonged exposure to this factor leads to changes in the nervous system. The work also discusses research done on the effects of the biological work-sleep-rest cycle.

Conclusions: It was shown that the greatest contribution to the study of aviation and space medicine was made by works utilizing biochemical, physiological and morphological methods using radioisotopes, which highlighted the advantage of their use during their study period.

Keywords: pilots, astronauts, cosmonauts, astronautics, animal radioisotope studies, hypodynamics, hypokinesia, vibration, simulated weightlessness

References: 34 • Full-text PDF: http://www.pjamp.com • Copyright (C 2013 Polish Aviation Medicine Society, ul. Krasińskiego 54/56, 01-755 Warsaw, license WIML • Indexation: Index Copernicus, Polish Ministry of Science and Higher Education 


\section{INTRODUCTION}

The development of space medicine began at the onset of the 1950's. In the first stage of research, the physical conditions of the orbital flight environment were identified. These findings stimulated the development of space medicine and monitoring of the impact of external environmental factors on human and animal organisms. Gathering of data concerning the behavior of humans and animals under conditions resembling future orbital flights has begun.

Intensive development of these studies took place in the second half of the 20th century. During this period, laboratory tests simulating the conditions of space flight were performed and the first launches of animals into space in rockets and sputniks took place. The authors identified a range of biological obstacles that needed to be addressed in order to conquer space. These works clearly underscored the study of the interaction between the body and the external environment. Studies performed under the conditions resembling future prolonged human presence in orbital flights involved mainly the animals.

During this time, the issue of overcoming the Earth's gravity during rocket take-off and landing was resolved. The design of rockets and spacecraft seats with adjustable positioning in relation to the acting acceleration was improved.

Finding a solution to overcome the effects of weightlessness proved to be a much more difficult challenge. Early spaceflights have shown that short-term weightlessness had no significant physiological effects on the animals. This suggested that short-term orbital flights should not pose a major threat to human life.

The first orbital flights involving animals partially resolved issues concerning short-term presence of organisms in the changing conditions of an external environment. Nonetheless, the accomplishments preceding Gagarin's flight could not resolve all the uncertainties. It was assumed that with prolonged human presence in space new problems would emerge. Experts anticipated that prolonged weightlessness would adversely affect the functions of the human body, especially upon returning to the Earth's gravity.

Consequently, a great deal of information from around the world concerns mostly the effects of weightlessness on an organism. The development of safety devices designed to protect the human life made the first flight by Yuri Gagarin possible.

With their technical capabilities, the United States and the former Soviet Union played domi- nant roles in resolving the problems of prolonged human space flight.

Scientific research concerning aviation and space medicine was already being performed in the 1960's as part of the Soviet space program Interkosmos $[3,4]$. This investigation found no evidence of persistent disorders of humans and animals caused by short-lived states of weightlessness [27,30].

It should be emphasized that during the initial space flights, MIAM already conducted research that could have been partly attributed to the problems of space medicine.

\section{METHODS}

The first research performed at MIAM evaluated the physical endurance of pilots. Its results did not differ from similar studies conducted by other countries. The object of the research $[19,22]$ was to determine the correlation between the physical capacity and the tolerance of flight. It revealed correlations between the tolerance of body position changes relative to the Earth's gravity, the effects of acceleration, hypoxia and physical endurance. Increasing the organism's tolerance for the effects of these factors could have helped prepare the organism for its readaptation following the return from orbital flight. However, the complete absence of a relationship between high physical endurance and tolerance of acceleration was only beneficial on the ground and not in a weightless environment. Reinforcement of this motor characteristic was necessary in pilots involved with high acceleration flights.

In their quest to find training methods that would improve the tolerance of acceleration and motor coordination of the body, the scientists at MIAM turned their attention to forms of physical education that combined the physiological mechanisms for coping with physical stress and the changes associated with the elements of flight. Physical exercise routines and training equipment were developed to stimulate the body's tolerance of acceleration in the different body axes and rapid changes of its position [32]. It should be emphasized that these physical training exercises were routinely conducted during physical training of aviation pilots, as well as those preparing for space flight.

Physical training was analyzed for its impact on acceleration tolerance in the animals. For this purpose, rats were subjected to daily swimming exercises for a period of 1 month [33]. Swimming 
was continued until the maximum level of animal fatigue was reached, as revealed by cessation of swimming, which was the limit of their exercise tolerance. It was found that the benefits of overload tolerance training were dependent on the baseline physical endurance of the animals. One could assume that, in comparison to control animals that performed ground physical exercises in "a spinning wheel", overload tolerance was the differentiating factor in terms of resistance to fatigue. It has been shown that this type of training improved the animals' tolerance in a centrifuge acceleration, although such was not the case in all the animals. This confirmed an already known fact that high physical endurance does not correlate with acceleration tolerance.

The development of space research, as well as the prospect of long-term space flights set new tasks and challenges. They included the protection of the human body against the effects of prolonged weightlessness and related hypodynamics. This was reflected in the work of MIAM experts concerning the behavior of the cardiovascular system and the function of body organs, which was studied using hypokinesia and myorelaxation [26].

Weightlessness in laboratory conditions was achieved using "fluid immersion" and restriction of movement of animals or humans. In humans, the fluid immersion method was mainly used for studying the impact of short-term weightlessness on the function of the cardiovascular and gastrointestinal systems. Earlier studies utilizing these methods as models for imitation of weightlessness have shown reduction in exercise capacity following various periods of immobilisation in the supine position with slight lowering of the head in the horizontal orientation [21,25]. It was found that following a period of a few days or weeks of immobilization in the supine position, the physical capacity of humans decreases $[2,16]$. The resulting hemodynamic dysfunction consisted of increased pooling of blood in the vascular areas of the head and the chest, which was analogous to the cephalization observed in all astronauts in the early days of orbital flights.

Fluid immersion method was also used in the animals by immersing them for periods of few hours. This approach analyzed the secretory function of the stomach and the intestines $[28,29]$. It was impaired peristalsis, the secretory activity of digestive juices and the digestive process. MIAM researchers also evaluated the circulatory system and found no disturbances associated with shortterm weightlessness. Studies of relative weightless obtained with this method have shown that short-term weightlessness does not lead to the cardiovascular system dysfunction.

Fluid immersion method was also used to determine the absorption of various types of compounds within the gastrointestinal tract of [7]. The implementation of ${ }^{51} \mathrm{Cr}$-myoglobins has demonstrated protein malabsorption in the digestive system of animals subjected to 6 hours of functioning in a weightless environment.

Studies of animals exposed to longer periods of hypokinesia without fluid immersion, were used to examine changes in the skeletal muscle, endocrine glands, nerve endings and cardiac muscle infarction. For this purpose, the animals were immobilized in cages restricting transverse movement of the body. Cage design made it possible to place the animal in a position with a portion of the pelvis and hind limbs raised along with lowered position of the head at an angle of $15^{\circ}$. This resulted in greater blood flow to the upper areas of the body and imitated cephalization in the space throughout the study period [9].

The use of isotopically-labeled compounds facilitated the development of various new research methods, which in many cases proved to be quite sensitive and accurate $[5,14]$. This allowed for the monitoring of even minor changes in the functioning of an organism and in some instances individual organs. Given the wide range of research possibilities provided by isotopes, it was surprising to learn that very little research in the field of aviation and space medicine utilized this method.

The use of radioactive isotopes in the setting of hemodynamic and bioelectric muscle dysfunction of rats subjected to the effects of acceleration has been the subject of research of MIAM scientists $[15,31]$. The research was conducted on rats placed in centrifuge containers that prevented the movement of the animals along the longitudinal axis, which enabled the study of the influence of overload on the function along the head-pelvis axis. Appropriate animal groups were subjected to: prolonged 8-week hypokinesia or the effects of acceleration, and the combined effects of hypokinesia and acceleration. In order to evaluate hemodynamic changes, the animals were administered ${ }^{131} \mathrm{~J}$-albumin. After 1 hour, the test animals were subjected to $+5 \mathrm{Gz}$ acceleration for a period of 15 minutes, 1 hour, 2 or 3 hours. Following a period of acceleration, the animals were anesthetized and bled. Next, muscle biopsies of the forelimbs and hindlimbs were taken and the level of radioactivity was measured. Additionally, a method of freezing the animals during acceleration was used by pouring liquid nitrogen into the container, al- 
lowing for an immediate fixation of the changes of the entire body system. Differences in the distribution of the isotope within the bodies of the animals were determined by scintigraphy.

Isotope search results have shown an increase in its radioactivity consistent with the vector of the overload, which was mainly localized in the hindlimbs. It was found that an earlier restriction of limb movements lead to the occurrence of trophic muscle changes, particularly at the cellular level. Changes progressed with the duration of the spin, which is likely associated with extravascular passage of ${ }^{131} \mathrm{~J}$-albumin. This was confirmed by scintigraphic studies. Animals subjected to combined action of hypokinesia and acceleration, hemodynamic dysfunction appeared much earlier and intensified with the duration of the spin. In comparison to the control group, these animals displayed significantly lower tolerance of acceleration. Vascular congestion of organs intensified with the progression of overload. It was also found that hemodynamic dysfunction was associated with higher permeability of low molecular weight proteins. Increased changes in the permeability of ${ }^{131} \mathrm{~J}$-albumin were already observed after $15 \mathrm{~min}$ utes of centrifugation, suggesting that the intensity of these changes will increase, despite the fact that the applied acceleration time was still within full compensation capabilities of the cardiovascular system.

Explanation of these findings required additional studies. Using the previously described methodology, we conducted additional studies with the administration of ${ }^{51} \mathrm{Cr}$-globumin. The results of these studies revealed no differences in the radioactivity of the forelimb and hindlimb muscles. This indicated that the permeability of high molecular weight proteins, even at prolonged acceleration time, has not yet reached such proportions and the observed changes were due to extravascular passage of proteins.

Using this same method, MIAM researchers analyzed the impact of hypodynamics in rats placed with the pelvis raised at an angle of $15^{\circ}$ for a period of 8 weeks under the conditions of hypokinesia and subjected to $+5 \mathrm{Gz}$ acceleration for a period of 1 hour $[5,18]$. Histopathological analysis of cellular changes revealed degenerative changes of the muscular system, a decrease in the number of mitochondria in the cells and disorders of systems regulating the functions of the body, including brain nerve centers.

Using the same methodology, Edelwejn observed much more pronounced changes by conducting electromyographic studies [EMG].
He demonstrated that the effect of $+5 \mathrm{Gz}$ within 3 hours induces a marked increase in the percentage of multi-phase potentials, while concomitantly increasing their amplitude [20]. He suggested that the reason for the observed changes was due to altered muscular blood flow as a result of blood pooling in the rear areas of the body. He stated that the immobilization of animals for a period of 8 weeks resulted in EMG changes with the appearance potentials of single fibrillar tremors. He explained these changes as a consequence of hypokinesia leading to muscle wasting caused by ischemia of the limbs. He argued that the brain stem is the main area of dysfunction caused by various afferent and efferent impulses. Data analysis has shown that subjecting the animals to the combined action of hypodynamics and acceleration produced changes in the function of the entire peripheral neuron, including anterior horn cells of the spinal cord. The observed EMG correlated with the results of the circulatory dysfunction.

Czerski and Wojtkowiak examined the changes in vascular permeability using Keta test and demonstrated the movement of blood which could cause vascular damage leading to the increased vascular permeability to ${ }^{22} \mathrm{Na}-\mathrm{NaCl}$ during $+3 \mathrm{Gz}$ acceleration for a period of 3 hours [17]. Acceleration parameters repeated over a number of days displayed significant histopathological changes in the vessels of the hind limbs, characterized by swelling of the blood vessels, which appeared as liquid protein saturation. These studies suggested that exposure to repeated acceleration has a cumulative effect on the adverse effects within the body.

MIAM researchers conducted radioisotope and morphologic studies on the effects of repeated acceleration on the small blood vessels. Tests were performed on rats subjected to $+3 \mathrm{Gz}$ acceleration, 3 hours daily for a period of 22 days [8]. The animals were administered ${ }^{131} \mathrm{~J}$-albumin and ${ }^{22} \mathrm{Na}-\mathrm{NaCl}$ isotonic solution before and after the experiment. After putting the animals to sleep, biopsies of the muscle, lung, liver, spleen and kidney tissues were taken. Tissue sections were examined histologically. The average half-life of ${ }^{22} \mathrm{Na}-\mathrm{NaCl}$ activity at the injection site in centrifuged animals was reduced to about half the original value, while ${ }^{131} \mathrm{~J}$-albumin passed through the walls of precapillary vessels. The observed behavior of radioactive isotopes was explained by the increasing rate of blood flow through the examined tissues, which confirmed a significant increase in vascular permeability. These changes were confirmed by the results of morphological and scintigraphic studies. It was suggested that more attention should 
be paid to the vascular and tissue changes of organs created under the influence of repeated acceleration.

Hemodynamic modifications at the cellular level also occur during sudden changes in the barometric pressure. In order to evaluate this problem, an "in vitro" ${ }^{35} \mathrm{~S}$-methionine method was used to assess the basic functions of the liver in animals previously subjected to explosive decompression $[1,2,17]$. No impairment in the metabolic functions was found as a result of these studies. On the other hand, changes in the cellular membrane permeability were demonstrated using ${ }^{42} \mathrm{~K}-\mathrm{KCl}$. The experiments were conducted in an attempt to develop an analogous set of studies for the causes of aviation accidents. It was believed that such approach would help conclude if the pilot was subjected to hypoxia or explosive decompression due to sudden cabin leak prior to the accident.

MIAM also carried out research concerning the impact of sudden decompression of animals in a hypobaric chamber $[13,14]$. It was discovered that, in animals, the effects of sudden decompression to $30000 \mathrm{~m}$ in $0.5 \mathrm{~s}$. or up to $20000 \mathrm{~m}$ in $2 \mathrm{~s}$, with $6000 \mathrm{~m}$ descent within $2 \mathrm{~s}$. result in pulmonary changes manifested by hemorrhages, alveolar ruptures and symptoms of atelectasis, emphysema and edema. Significant congestion in other organs was also observed.

Barański S. [2] conducted studies of mice by administering ${ }^{35} \mathrm{~S}$-methionine and ${ }^{32} \mathrm{P}$-phosphate to animals subjected to prolonged hypoxia at $8000 \mathrm{~m}$ over a period of 6 to 48 hours. Studies have shown lowered levels of these compounds as expressed by their reduced incorporation into the brain tissue. This concerned the lipid and nucleoprotein fractions, with a clear reduction of the lipid fraction.

The issue of vibration was also the subject of the study. Barański S. and Jurczak M. [10] performed studies by subjecting the animals to a vertical sinusoidal vibration using a constant $8 \mathrm{G}$ acceleration and variable frequency and amplitude of vibration. Frequencies used included 20, 40 and $70 \mathrm{~Hz}$ with respective amplitudes of 5, 1.25 and $0.4 \mathrm{~mm}$.

Macroscopic studies revealed increased congestion of the pulmonary parenchyma accompanied by significant hemorrhage and severe congestion of the spleen, kidney, liver and the heart muscle. Brain and meningeal blood vessels were heavily filled with blood. Histological examination confirmed the changes.

Performed macro and microscopic evaluations show that circulatory disorders are uniformly associated with all parameters of vibration. Extent of these changes depends on the amplitude of vibration. The largest changes occur at low frequencies and low amplitudes.

The effects of vibration frequency of $50 \mathrm{~Hz}$ and amplitude of $0.0394 \mathrm{~mm}$ in terms of ${ }^{32} \mathrm{P}-\mathrm{Na} 2 \mathrm{HPO} 4$ conversion within the central nervous system have been the subject of a study by Jurczak [23]. Results of these studies have shown that exposing an organism to a single episode of vibration increases ${ }^{32} \mathrm{P}-\mathrm{Na} 2 \mathrm{HPO} 4$ in the lipid and nucleoprotein fraction. However, with progression of time, there is a tendency of the body to return to normal state of functioning.

Exposure of the body to chronic vibrations [24] for a period of 6 days, 3 hours daily, leads to a large reduction in the conversion and incorporation of ${ }^{32} \mathrm{P}-\mathrm{Na} 2 \mathrm{HPO} 4$. Return to baseline was observed after a period of 10 days following the completion of the study.

Based on these studies it can be assumed that vibrations generated during rocket launch are too short-lived to induce such changes in the body.

Studies conducted at MIAM have helped establish harmful effects of chronic vibration on the following systems: circulatory, nervous, osteoarticular, endocrine and gastrointestinal. The experiments revealed that all changes in the body systems, especially the nervous system, are preceded by metabolic dysfunction of nucleoproteins and phosphoproteins, and that the severity of these changes depends on the duration of the stimulus. It has also been shown that the effect of vibration on the function of the secretion of adrenal hormones and the thyroid is largely that of stress.

The use of isotopically-labeled compounds facilitated the development of various new research methods, which in many cases proved to be quite sensitive and accurate. This allowed for the monitoring of even minor changes in the functioning of an organism and in some instances individual organs.

Research was conducted on biosputniks 936 and 782 as part of the Interkosmos scientific program adopted by Poland. In 1975, MIAM joining the research being conducted on animals during the 21-day space flight. The following animals were observed in different conditions:

- Those located on the biosputnik;

- Those subjected to factors acting in space immediately following landing;

- Those undergoing readaptation back on Earth for a period of 2 weeks.

All of these animals were analyzed in comparison with the control group. 
The following organs were the subject of observation by MIAM researchers: heart muscle, skeletal muscle, adrenal gland and bone tissue $[6,9]$. Preliminary observations have shown changes in both qualitative and quantitative structure of striated muscle fibers in animals undergoing 21-day spaceflight.

As a result of these studies, it was confirmed that:

1. Chronic irradiation of mice testicular tissue with 137 Cs leads to degenerative changes in the seminiferous epithelium, non-regenerating even at 6 months after irradiation. It was also shown that non-steroidal drugs, Indomethacin and Suprofen, possess radioprotective qualities.

2. Animal studies performed immediately following an orbital flight revealed that the combined effect of hypoxia along with high and low temperatures induces morphological changes in the glands of the endocrine system of rats.

3. The authors demonstrated that during the animals' readaptation period following spaceflight, the use of low-oxygen compounds, a 2-hour exposure to low accelerations $+\mathrm{Gz}$ and the reversal of light-darkness phase, desynchronize the circadian rhythm. The rhythm of insulin secretion, triiodothyronine, corticosterone and glucose was also altered.

4. The authors obtained data concerning nystagmus and the frequency of motion sickness by utilizing the Coriolis prolonged acceleration method. It has been found that the administration of Torecan and Diphergan suppresses the incidence of these symptoms.

The work performed during the Interkosmos scientific program included studies on the behavior of striated muscle and heart muscle of rats subjected to 3 and 6 month periods of hypodynamia. The animals were exposed to $5 \mathrm{Gz}$ acceleration for periods of time ranging from 15 to 180 minutes. Histological and histochemical studies of tissue, ECG, EMG and nerve conduction velocity studies were also performed.

Muscle cell mitochondrial degeneration, including partial loss of muscle fibers and connective tissue proliferation were observed [9]. Histochemical studies revealed reduced levels of glycogen, and increased levels of lactic acid dehydrogenase and succinic acid, especially following exercise. Nerve conduction velocity studies showed decreased values. Acceleration tolerance was also reduced.

Studies concerning the effects of long-term hypokinesia may be regarded as model experiments that allow for laboratory monitoring of parameters of reduced gravity and the endocrine system.
These studies have provided a number of factors necessary to assess an organism's disturbances in the setting of weightlessness. The studies also made it possible to identify appropriate preventive measures.

The study of biological rhythms became another topic undertaken by the researchers at MIAM. In this project, particular attention was paid to the effects of space flight and the desynchronization of circadian rhythm in terms of endocrine secretions and carbohydrate metabolism [12]. The authors presented the current issues of biological rhythms associated with aerospace medicine. They described the subject of night flights, time zone crossings and the results of space experiments. According to the authors, the most important factor is a proper maintenance of the astronaut's sleepwake cycle, which may affect their endurance and proper psychomotor performance. Problems with sleep adaptation result from the light-darkness cycle occurring every 90 minutes during each circling of the Earth. Research indicates that the presence of 24-hour lighting could lead to desynchronization of internal rhythms or dysrhythmia [34]. Consequently, the authors suggested that a sleepwake-work cycle be initiated in the period before the flight in an attempt to synchronize the biological rhythms. The issues of chronobiology with particular emphasis on cytological aspects were presented by Barański S., Kwarecki K. and Szmigielski S. [11]. The authors described a concept of the action of endogenous biological clock. The content of their work explains both the endogenous nature of biorhythms of genetic origin in combination with adjustable synchronization with environmental factors, and the mechanism for the transmission of information from a master clock.

In 1976, MIAM was assigned to perform the selection and preliminary preparations of Polish candidates for manned orbital flight.

\section{CONCLUSIONS:}

The presented work only summarizes the results of studies performed by MIAM researchers. It should be emphasized that numerous studies have indicated that the greatest contribution to the study of aviation and space medicine was made by works involving biochemical, physiological and morphological methods utilizing radioisotope methods, further emphasizing the usefulness of their implementation during the period. 
M. Wojtkowiak - Selected problems...

\section{AUTHORS' DECLARATION:}

Study Design: Mieczysław Wojtkowiak; Data Collection: Mieczysław Wojtkowiak; Manuscript Preparation: Mieczysław Wojtkowiak; Funds Collection: Mieczysław Wojtkowiak. The Author declares that there is no conflict of interest.

\section{REFERENCES}

1. Barański, S. (1962) Badania nad wbudowywaniem się związków znaczonych izotopami promieniotwórczymi do ośrodkowego układu nerwowego w przebiegu niedotlenienia wysokościowego. Medycyna Lotnicza. 8.15-62.

2. Barański, S. (1963) Incorporation of 35S-methionine into the central nervous system of white mice during altitude hypoxia. Biulletin de l'Academie Polonaise des Sciences. 5. 255-59.

3. Barański, S. (1974) Osiągnięcia i perspektywy rozwoju medycyny lotniczej. Lekarz Wojskowy. 8. 606-12.

4. Barański, S. (1973) Wydolność i adaptacja w warunkach współczesnych lotów wysokościowych i kosmicznych. Acta Physiol Pol. XXIV. 5. Suplement 7.

5. Barański, S. (1967) Zastosowanie izotopów radioaktywnych w badaniach doświadczalnych w medycynie lotniczej i kosmicznej. Medycyna Lotnicza. 21/22. 79-101.

6. Barański, S., Barańska, W., Kujawa, M. (1973) Wlijanie dlitjelnoj gipokinezji i fizjiczeskoj nagruzki na funkcju i morfołogii serdecznoj myszcy. (in Russian) Interkosmos. 27 May - 2 June. Proceedings from Sympozjum Biologii i Medycyny Kosmicznej. 473-482.

7. Barański, S,. Czerski, P., Jurczak, M. (1964) Investigations on the functions of the digestive tract in immersion subgravity. Proceedings of the XV International Astronautical Congress.

8. Barański, S., Edelwejn, Z., Barańska, W. (1976) Effect of Long-Term Hypodynamia and Hypokinesia on The Functional State and Ultrastructure of Striated Muscles. Artificial Satellites. 11. 15-28.

9. Barański, S., Edelwejn, Z., Wojtkowiak, M. (1970) Hemodynamic and bioelectric disturbances in striated muscle of rats during acceleration exposure after period of hypokinesia. Space Live Science. 2. 400-403.

10. Barański, S., Jurczak, M. (1966) Badania morfologiczne nad wpływem wibracji na ustrój świnki morskiej. Medycyna Pracy. XVII. 410-418.

11. Barański, S., Kwarecki, K., Szmigielski, S. (1972) Współczesne zagadnienia chronobiologii ze szczególnym uwzględnieniem aspektów cytologicznych. Medycyna Lotnicza. 38. 15-30.

12. Barański, S., Kwarecki, K., Szmigielski, S. (1972) Znaczenie rytmów biologicznych dla medycyny lotniczej i kosmicznej. Medycyna Lotnicza. 38. 65-73.

13. Barański, S., Szamborski, J. (1960) Badania morfologiczne nad wpływem nagłych zmian ciśnienia na ustrój zwierzęcia. Lekarz Wojskowy. 5. 475 - 490.

14. Barański, S., Szmigielski, S. (1967) Badania morfologiczne zachodzące w ustroju białych szczurów podczas eksplozywnej dekompresji przeprowadzanej w czasie od 0,0001 do 0,0003 sek. Medycyna Lotnicza. 21/22. 103-110.

15. Barański, S., Wojtkowiak, M. (1970) Badania przemieszczania się białek osocza krwi u szczurów poddanych działaniu przyspieszeń. Postępy Astronautyki. 4. 5.

16. Birkhead, N.C., Blizzard, J.J., Daly, J.W., Haupt, G.J., Issekutz, B., Myers, R.N., Rodahl, K. (1963) Cardiodynamic and Metabolic Effects of Prolonged Bed Rest. Aerosp. Med. 40, Rep. No. AMRL - 63.

17. Czerski, P., Wojtkowiak, M. (1967) Radioizotopowe i morfologiczne badania nad wpływem wielokrotnego działania przyspieszeń na małe naczynia krwionośne. Medycyna Lotnicza. 21/22. 139-141.

18. Czerski, P., Wojtkowiak, M., Zaremba, H. (1969) Oddziaływanie przyspieszeń na ustrój ludzki i zwierzęcy. Postępy Astronautyki. 4. 113.

19. Dziuk, Z., Sulajnis, H., Wojtkowiak, M. (1969) Ocena współzależności między znoszeniem przyspieszeń w osi +Gz, wynikami prób czynnościowych a rozwojem wybranych cech motorycznych. Postępy Astronautyki. 4. 49-56.

20. Edelwejn, Z. (1968) Badania czynności bioelektrycznej mózgu. Acta physiol. Pol. 19. 897.

21. Gauer, O.H., Henry, J.P. (1964) On the triggering mechanism of vasovagal cardiovascular combination of lower body negative pressure and head-up tilt. Aerosp. Med. 1 (35). 533-45.

22. Jethon, Z., Sarol, Z., Dziuk, Z., Wojtkowiak, M. (1964) Wartość wybranych wskaźników kondycji fizycznej w lotnictwie. Wych. Fiz. i Sport. 3. 327-35.

23. Jurczak, M. (1966) Badania nad przemianą ${ }^{32} \mathrm{P}$ w ośrodkowym układzie nerwowym w czasie jednorazowego wystawienia zwierząt na czynnik wibracyjny. Acta Physiol.Pol. 2. 203-13. 
24. Jurczak, M. (1966) Wpływ przewlekłego oddziaływania wibracji na przemianę fosforanu ${ }^{32} \mathrm{P}$ w ośrodkowym układzie nerwowym. Acta Physiol. Pol. 5-6. 743-53.

25. Miller, P.B., Leverett, S.D. (1965) Tolerance to transverse (+Gx) and headward (+Gz) acceleration after prolonged bed rest. Aerosp. Med. 36. 1-13.

26. Walawski, J. (1974) Physiological principles of the space flight and human life in space. Acta Physiol.Pol. 25. 131-44.

27. Walawski, J. (1963) Role of medicine in space. Acta Physiol. Pol. 25 (18). 461-5.

28. Walawski, J, Kaleta, Z. (1963) Some circulatory reactions during the course of prolonged weightlessness produced by the immersion method. Acta Physiol Pol. 7/8. 399-403.

29. Walawski, J., Kaleta, Z. (1968) Vascular reactions to neurohormons to prolonged subgravity correlated with low and high environmental temperature. Proceedings of XXIV International Congress, Washington D. C.

30. Wojtkowiak, M. (1974) Haemodynamic changes caused in rats by prolonged accelerations. Life Science and Space Research. 12. 103-5.

31. Wojtkowiak, M. (1977) Normalization of hemodynamic changes caused by action of prolonged acceleration in rats. Life Science and Space Res. 12. 103-6.

32. Wojtkowiak, M.( 1989) Wybrane ćwiczenia fizyczne pilotów do wykonywania prób krążeniowo-oddechowych zwiększających tolerancję przyspieszenia. Postępy Astronautyki. 1/2. 83-94.

33. Wojtkowiak, M., Domaszuk, J., Janusewicz, M. (1977) Wpływ treningu fizycznego specyficznego i niespecyficznego na poziom tolerancji +Gz u szczurów. Postępy Astronautyki. 93-97.

34. Zużewicz, K. (1991) Charakterystyka okołodobowych rytmów biologicznych człowieka w wysokich szerokościach geograficznych $\left(77^{\circ}-80^{\circ}\right)$. Kosmos. 40. 357-72.

Cite this article as: Wojtkowiak M: Selected Problems of Space Medicine. Early Physiological Pesearch at the Military Institute of Aviation Medicine. Pol J Aviat Med Psychol, 2013; 19(3): 37-44. 